\title{
ANALISIS KESALAHAN SISWA DALAM MENGERJAKAN SOAL-SOAL FISIKA TERMODINAMIKA PADA SISWA SMA NEGERI 1 MAGETAN
}

\author{
Suroso \\ SMAN 1 MAGETAN, Dinas Pendidikan Kabupaten MAgetan \\ E-mail:dhesuroso@gmail.com
}

\begin{abstract}
Abstrak
Temuan dilapangan beberapa jenis kesalahan dan penyebab kesalahan yang dilakukan oleh siswa dalam menyelesaikan soal-soal Fisika bahasan Termodinamika adalah: (1) Kesalahan terjemahan (58,24\%) berupa kesalahan dalam menuliskan apa yang diketahui dan ditanyakan pada soal ke dalam simbol Fisika, memahami maksud soal, serta menuliskan data yang diketahui pada soal secara tepat. (2) Kesalahan konsep $(57,14 \%)$ berupa kesalahan dalam memahami konsep usaha yang dilakukan lingkungan pada sistem, proses Termodinamika, usaha pada proses Termodinamika, kapasitas kalor, Hukum I Termodinamika, perubahan energi dalam, siklus termodinamika, mesin Carnot, perubahan entropi, dan mesin pendingin, serta mengkonversikan ke Satuan Internasional (SI). (3) Kesalahan strategi $(60,44 \%)$ berupa kesalahan dalam menggunakan data dan dalam penentuan langkah penyelesaian soal. (4) kesalahan hitung (34,07\%) berupa kesalahan dalam melakukan operasi hitung.
\end{abstract}

Kata kunci : Analisis Kesalahan, Menyelesaikan Soal, Termodinamika

\section{PENDAHULUAN}

Fisika adalah salah satu cabang ilmu pengetahuan alam yang mempelajari tentang alam dan seisinya serta perubahan-perubahan yang terjadi didalamnya. Tujuan pembelajaran fisika adalah untuk membentuk kemampuan berpikir kritis, logis dan sistematis dan memiliki sifat objektif, jujur, disiplin dalam memecahkan suatu permasalahan baik dalam bidang fisika maupun bidang ilmu lain, maupun kehidupan sehari-hari.

Dalam pembelajaran di sekolah jarang diajarkan tentang contoh penerapan Fisika dalam kehidupan sehari-hari. Sehingga siswa merasa Fisika merupakan pelajaran yang tidak bermanfaat setelah lulus nantinya. Selain itu, pelajaran Fisika juga dianggap sulit karena banyak rumus dan hitungan. Seperti yang diungkapkan Suparno (2009: 2) bahwa beberapa siswa SMA tidak menyukai Fisika dan akhirnya memilih jurusan yang tidak ada pelajaran Fisika karena Fisika dianggap menakutkan, sulit dipelajari, banyak hitungan dan rumus. Beberapa siswa SMA mengeluh kesulitan dalam belajar Fisika sehingga sering terjadi kesalahan dalam mengerjakan soal. Mereka merasa lebih baik menghindari Fisika daripada menemui kesulitan jika belajar Fisika. Kalau mereka terpaksa belajar Fisika, sesungguhnya kebanyakan dari mereka hanya sekedar mengikuti untuk memenuhi kewajiban pelajaran di sekolah, bukan berusaha untuk memahaminya. Penyebab siswa kesulitan belajar Fisika antara lain adanya perbedaan dalam penyajian pembelajaran Fisika dalam waktu yang sama seperti yang diungkapkan Ornek (2008: 30), "Students find physics difficult they have to contend with different representations such as experiments, formulas and calculations, graphs, and conceptual explanations at the same time".

Pada proses pembelajaran Fisika, siswa dibimbing menyelesaikan soalsoal. Tujuan siswa dibimbing menyelesaikan soal-soal Fisika adalah agar ketika dihadapkan pada soal-soal Fisika, siswa mampu menyelesaikannya dengan baik. Akan tetapi, masih terdapat siswa yang melakukan kesalahan dalam menyelesaikan soal-soal Fisika. Banyak faktor yang mungkin menyebabkan kesalahan yang dilakukan oleh siswa. Faktor-faktor tersebut dapat berasal dari dalam atau luar diri siswa. Faktor dari dalam diri siswa dapat berupa motivasi, minat, dan bakat siswa. Faktor dari luar diri siswa dapat berupa kondisi lingkungan, keluarga, guru, teman, dan bahan belajar.

Termodinamika merupakan salah satu cabang ilmu Fisika yang memusatkan perhatian pada energi (terutama energi panas) dan transformasinya. Transformasi energi pada termodinamika berlandaskan pada dua hukum, yaitu hukum pertama termodinamika (hukum kekekalan energi) dan hukum kedua 


\section{JEMS (Jurnal Edukasi Matematika dan Sains)}

Tersedia online di: http://e-journal.ikippgrimadiun.ac.id/index.php/JEMS

Volume 4, Nomor 1, Maret 2016, hal 8 - 18

termodinamika yang memberi batasan apakah suatu proses dapat berlangsung atau tidak.

Keberhasilan proses belajar ditunjukkan dengan adanya perubahan perilaku yang cenderung menetap dan biasanya terlihat pada prestasi belajar yang baik. Proses belajar tidak selalu berhasil baik. Hal tersebut disebabkan adanya hambatan dalam proses belajar. Berhasil atau tidaknya proses belajar mengajar Fisika dapat dilihat dari kemampuan siswa dalam menyelesaikan soal pada materi yang telah diajarkan. Ketidakberhasilan dari proses belajar dapat ditunjukkan dengan adanya kesalahan yang dilakukan siswa dalam menyelesaikan suatu persoalan. Kesalahan merupakan hal yang wajar. Akan tetapi apabila dibiarkan saja, tujuan dari pembelajaran Fisika tidak dapat tercapai secara optimal.

Yusro (2015) materi termodinamika merupakan materi fisika yang banyak memuat konsep-konsep yang mengarah kepada kehidupan sehari-hari dan pemanfaatan teknologi. Termodinamika merupakan salah satu materi yang dipelajari pada Semester Genap kelas XI SMA. Pada materi ini sering terjadi berbagai kesalahan sehingga mengakibatkan hasil belajar tidak maksimal. Hal ini dikarenakan karakteristik bahasan Termodinamika yang termasuk sulit, yaitu konsep usaha lingkungan ke sistem dan sebaliknya yang masih membuat siswa bingung, terdapat empat proses Termodinamika dengan berbagai penerapannya, konsep mesin Carnot dan mesin pendingin yang masih membuat siswa bingung, serta banyak penerapan rumus yang memerlukan perhitungan.

\section{METODE PENELITIAN}

Penelitian ini termasuk jenis penelitian deskriptif yang melalui pendekatan kualitatif yang didukung data kuantitatif. Pada penelitian deskriptif kualitatif ini digunakan data-data secara kualitatif yang didukung data kuantitatif dengan tujuan untuk mendeskripsikan jenis kesalahan dan penyebab kesalahan yang dilakukan siswa dalam menyelesaikan soal-soal Fisika pada bahasan Termodinamika.

Data dalam penelitian ini adalah kesalahan dalam penyelesaian soal-soal Fisika bahasan Termodinamika yang dilakukan oleh siswa kelas XI Mat-IA 3, XI Mat-IA 6, XI Mat-IA 7 dan XI Mat-IA 8 SMA Negeri 1 Magetan Semester Genap Tahun Pelajaran 2014/2015. Pengumpulan data dalam penelitian ini menggunakan beberapa teknik, yaitu tes, observasi dan wawancara. Teknik tes merupakan metode utama yang digunakan dalam mengumpulkan data pada penelitian ini, sedangkan observasi dan wawancara merupakan metode bantu sebagai pelengkap yang hasilnya digunakan sebagai pembanding dalam proses triangulasi. Tes dan observasi dilakukan pada siswa kelas XI Mat-IA yang berjumlah 91 siswa. Pemilihan siswa tersebut dilakukan menggunakan teknik purposive sampling untuk mengetahui jenis kesalahan dan penyebab kesalahan yang dilakukan siswa dalam menyelesaikan soal-soal Fisika bahasan Termodinamika. Oleh karena itu, dipilih kelas XI Mat-IA 3 yang mewakili kelas rendah, kelas XI Mat-IA 6 dan XI Mat-IA 7 yang mewakili kelas sedang, dan kelas XI Mat-IA 8 yang mewakili kelas tinggi, data yang diperoleh lebih mewakili informasi untuk memperoleh kedalaman studi tentang jenis kesalahan dan penyebab kesalahan yang dilakukan siswa dalam menyelesaikan soal-soal Fisika bahasan Termodinamika dan hasilnya tidak untuk digeneralisasikan karena data tidak diambil secara acak

\section{HASIL PENELITIAN DAN PEMBAHASAN}

\section{Hasil Kajian Dokumen Secara Umum}

Berdasarkan hasil analisis terhadap lembar jawaban siswa, dapat diketahui kesalahankesalahan yang dilakukan siswa dalam menyelesaikan soal bahasan Termodinamika. Jenis kesalahan yang dilakukan siswa adalah kesalahan terjemahan, kesalahan konsep, kesalahan strategi, dan kesalahan hitung.

\section{Kesalahan Terjemahan}

Kesalahan terjemahan yang dilakukan siswa berupa kesalahan dalam menuliskan apa yang diketahui dan ditanyakan pada soal ke dalam simbol Fisika, memahami maksud soal, serta menuliskan data yang diketahui pada soal secara tepat yang disebabkan siswa lupa, tidak memahami simbol Fisika dari data-data yang disebutkan pada soal, dan kurang teliti dalam membaca serta memahami maksud soal.

\section{Kesalahan Konsep}

Kesalahan konsep yang dilakukan siswa berupa kesalahan dalam memahami konsep usaha yang dilakukan lingkungan pada sistem, proses Termodinamika, usaha pada proses Termodinamika, kapasitas kalor, Hukum I Termodinamika, perubahan energi dalam, siklus 


\section{JEMS (Jurnal Edukasi Matematika dan Sains)}

Tersedia online di: http://e-journal.ikippgrimadiun.ac.id/index.php/JEMS

Volume 4, Nomor 1, Maret 2016, hal 8 - 18

Termodinamika, mesin Carnot, perubahan entropi, dan mesin pendingin, serta mengkonversikan ke Satuan Internasional (SI) yang disebabkan siswa kurang belajar, kurang memperhatikan penjelasan guru, dan tidak berani mengajukan pertanyaan ketika ada materi yang belum dipahami.

\section{Kesalahan Strategi}

Kesalahan strategi yang dilakukan siswa berupa kesalahan dalam menggunakan data dan dalam penentuan langkah penyelesaian soal yang disebabkan siswa lupa, kurang teliti, kurang latihan soal, kurang variasi dalam latihan penyelesaian soal, terburuburu, dan kekurangan waktu.

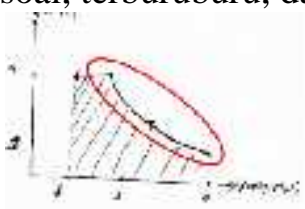

a.

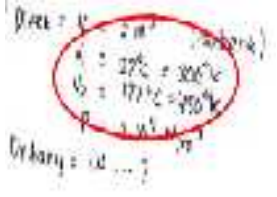

b.

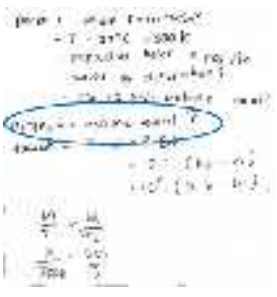

c.

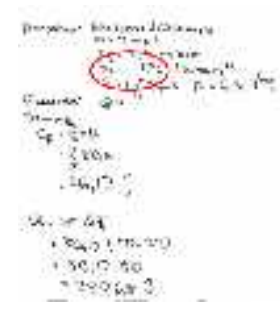

d.

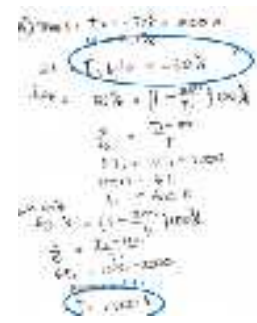

e.

Gambar 1. a. Kesalahan terjemahan pada soal no 2

b. Kesalahan terjemahan pada soal no 3

c. Kesalahan terjemahan pada soal no 4

d. Kesalahan terjemahan pada soal no 5

e. Kesalahan terjemahan pada soal no 8

Potongan jawaban siswa pada Gambar 1.a. memperlihatkan kesalahan terjemahan yang dilakukan pada soal nomor 2. Kesalahan terjemahan yang dilakukan siswa yaitu menggambar proses pemampatan isotermal dari volume $4.10^{-3} \mathrm{~m}^{3}$ atau 4 liter menjadi $2.10^{-3} \mathrm{~m}^{3}$ atau 2 liter, sedangkan dalam soal ditanyakan proses pemuaian isotermal dari volume 2 liter menjadi 4 liter. Penyebab kesalahan terjemahan yang dilakukan siswa dikarenakan siswa kurang teliti dalam memahami maksud soal. Gambar 1.b. potongan jawaban siswa pada soal no 3 kesalahan siswa disini, kesalahan terjemahan yang dilakukan siswa yaitu menuliskan suhu yang diketahui dalam soal dengan simbol V yang dalam Fisika berarti volume, sedangkan seharusnya dengan simbol T.

Jawaban siswa sperti pada Gambar 1.c. memperlihatkan kesalahan terjemahan yang dilakukan pada soal nomor 4. Kesalahan terjemahan yang dilakukan siswa yaitu Siswa menuliskan yang ditanyakan volume awal, sedangkan seharusnya kalor. Potongan jawaban siswa pada Gambar 1.d. memperlihatkan kesalahan terjemahan yang dilakukan pada soal nomor 5. Kesalahan terjemahan yang dilakukan siswa yaitu salah menuliskan data yang diketahui pada soal. Siswa menuliskan $\mathrm{T} 2=177^{\circ} \mathrm{C}$, sedangkan seharusnya $127^{\circ} \mathrm{C}$. Jawaban siswa pada Gambar 1.e. memperlihatkan kesalahan terjemahan yang dilakukan pada soal nomor 8 . Kesalahan terjemahan yang dilakukan siswa yaitu salah dalam mengartikan maksud soal. Siswa menuliskan bahwa yang ditanyakan T1 bila $\eta=60 \%$, sedangkan yang dimaksud dalam soal adalah banyak T1 yang dinaikkan jika $\eta=60 \%(\Delta \mathrm{T} 1)$. Beberapa bentuk kesalahan konsep yang ditemukan dalam lembar jawaban siswa terangkum dalam gambar 2.

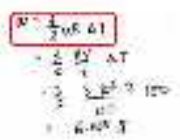

a.

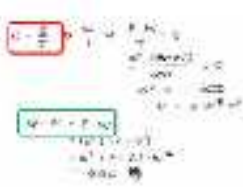

b.

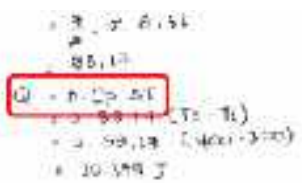

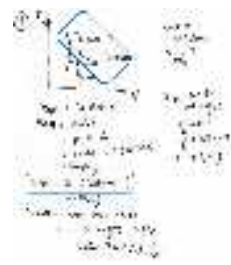

d.

Gambar 2. a. Kesalahan konsep pada soal no 3

b. Kesalahan konsep pada soal no 4 


\section{JEMS (Jurnal Edukasi Matematika dan Sains)}

Tersedia online di: http://e-journal.ikippgrimadiun.ac.id/index.php/JEMS

Volume 4, Nomor 1, Maret 2016, hal 8 - 18

\section{c. Kesalahan konsep pada soal no 5}

\section{d. Kesalahan konsep pada soal no 5}

Potongan jawaban siswa pada Gambar 2.a. memperlihatkan kesalahan konsep yang dilakukan pada soal nomor 3. Kesalahan konsep yang dilakukan siswa yaitu menuliskan persamaan usaha untuk proses isobarik dengan $W=\frac{3}{2} n R \Delta T$ sedangkan seharusnya dengan $\mathrm{W}=\mathrm{P}$ Vatau $\mathrm{W}=$ $\mathrm{n} \mathrm{R}$ T. Sedangkan untuk potongan jawaban siswa pada Gambar 2.b. memperlihatkan kesalahan konsep yang dilakukan pada soal nomor 4. Kesalahan konsep yang dilakukan siswa yaitu tidak memahami hubungan kalor $(\mathrm{Q})$, kapasitas kalor $(\mathrm{C})$, dan perubahan suhu $(\Delta \mathrm{T})$ dan menganggap nilai $\mathrm{Q}$ dan $\mathrm{W}$ pada proses isobarik sama, yaitu $\mathrm{Q}$ $=\mathrm{W}=\mathrm{P} \quad \mathrm{V}$.

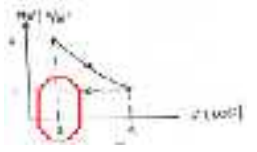

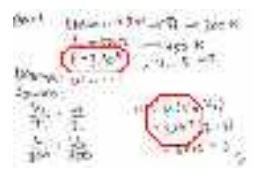

b.

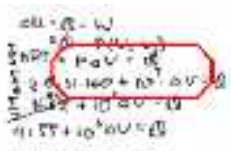

c.

Potongan jawaban siswa pada Gambar 4.15 memperlihatkan kesalahan konsep yang dilakukan pada soal nomor 5. Kesalahan konsep yang dilakukan siswa yaitu mengerjakan dengan persamaan $\mathrm{Q}=\mathrm{n} . \mathrm{CP} . \mathrm{T}$, sedangkan seharusnya $\mathrm{Q}=\mathrm{CP}$. T. Sedangkan untuk potongan jawaban siswa pada Gambar 2.d. memperlihatkan kesalahan konsep yang dilakukan pada soal nomor 6. Kesalahan konsep yang dilakukan siswa yaitu menganggap proses $\mathrm{BC}$ adalah isotermis, sedangkan seharusnya adiabatik karena suhu berbeda/tidak konstan, yaitu $600 \mathrm{~K}$ dan $400 \mathrm{~K}$.

Pada gambar 3 akan kita temukan beberapa contoh kesalahan strategi siswa dalam mengerjakan soal-soal fisika khususnya pada bahasan Termodinamika.

Gambar 3.

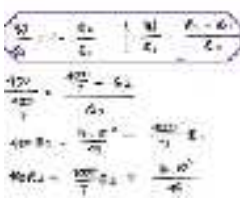

d.

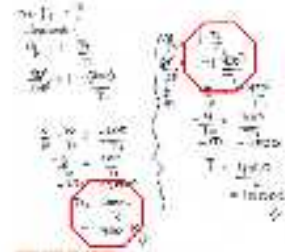

e.

\section{a. Kesalahan strategi pada soal no 2 \\ b. Kesalahan strategi pada soal no 3 \\ c. Kesalahan strategi pada soal no 5 \\ d. Kesalahan strategi pada soal no 7 \\ e. Kesalahan strategi pada soal no 8}

Potongan jawaban siswa pada Gambar 3.a memperlihatkan kesalahan strategi yang dilakukan pada soal nomor 2. Kesalahan strategi yang dilakukan siswa yaitu menggambarkan $\mathrm{V}=2$ liter pada proses isobarik, sedangkan dalam soal diminta menggambar sampai $\mathrm{V}_{\text {akhir }}=1$ liter. Sedangkan potongan jawaban siswa pada Gambar 3.b memperlihatkan kesalahan strategi yang dilakukan pada soal nomor 3. Kesalahan strategi yang dilakukan siswa yaitu mensubstitusikan besar tekanan $(\mathrm{P})=3 \cdot 10^{-5}$, sedangkan seharusnya 3. $10^{5}$.

Potongan jawaban siswa pada Gambar 3.c. memperlihatkan kesalahan strategi yang dilakukan pada soal nomor 5. Kesalahan strategi yang dilakukan siswa yaitu menggunakan cara yang rumit dan tidak tepat. Siswa mencari besar usaha dengan persamaan $W=r \cdot \Delta V$, sedangkan seharusnya dengan $W=n K \Delta T$. Sedangkan

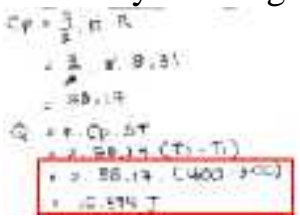

a.

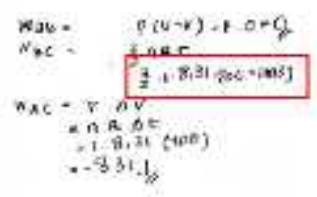

b. jawaban siswa pada Gambar 3.d. memperlihatkan kesalahan strategi yang dilakukan pada soal nomor 7. Kesalahan strategi yang dilakukan siswa yaitu salah mengubah persamaan $\frac{W}{Q_{1}}=1-\frac{Q_{2}}{Q_{1}}$ yang seharusnya menjadi $\frac{W}{U_{1}}=\frac{U_{1}-U_{2}}{U_{2}}$ yang seharusnya menjadi $\frac{W}{U_{1}}=\frac{U_{1}-U_{2}}{U_{1}}$. Potongan jawaban siswa pada Gambar 3.e memperlihatkan kesalahan strategi yang dilakukan pada soal nomor 8. Kesalahan strategi yang dilakukan siswa yaitu menggunakan data yang tidak tepat dengan mensubstitusikan $\mathrm{T}=$ $400 \mathrm{~K}$ sebagai $\mathrm{T}_{2}$.

Temuan-temuan kesalahan hitung yang dilakukan oleh peserta didik dalam mengerjakan soal-soal fisika khususnya bahasan Termodinamika terangkum dalam gambar 4 .

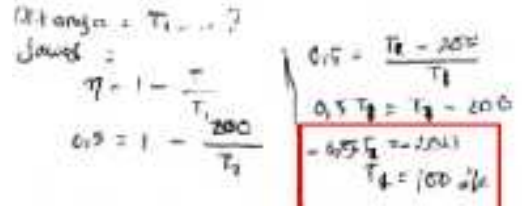

c.

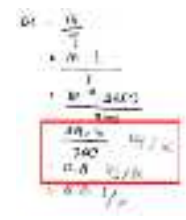

d. 
JEMS (Jurnal Edukasi Matematika dan Sains)

Tersedia online di: http://e-journal.ikippgrimadiun.ac.id/index.php/JEMS

Volume 4, Nomor 1, Maret 2016, hal 8 - 18

\section{Gambar 4. a. Kesalahan strategi pada soal no 5 \\ b. Kesalahan strategi pada soal no 6 \\ c. Kesalahan strategi pada soal no 8 \\ d. Kesalahan strategi pada soal no 9}

Potongan jawaban siswa pada Gambar 4.a memperlihatkan kesalahan hitung yang dilakukan pada soal nomor 5. Kesalahan hitung yang dilakukan siswa yaitu menghitung 2. 58,17. (400$300)=10374 \mathrm{~J}$, sedangkan seharusnya $11634 \mathrm{~J}$. Potongan jawaban siswa pada Gambar 4.b memperlihatkan kesalahan hitung yang dilakukan pada soal nomor 6. Kesalahan hitung yang dilakukan siswa yaitu menghitung $\frac{3}{2} \cdot 1$. $8,31(-200)=2493$, sedangkan seharusnya 2493.

Potongan jawaban siswa pada Gambar 4.c memperlihatkan kesalahan hitung yang dilakukan pada soal nomor 8. Kesalahan hitung yang dilakukan siswa yaitu menghitung $-0,5 \mathrm{~T}_{1}=$ -200 menjadi $\mathrm{T}_{1}=100$, sedangkan seharunya 400. Sedangkan potongan jawaban siswa pada Gambar 4.d memperlihatkan kesalahan hitung yang dilakukan pada soal nomor 9. Kesalahan

Tabel 1. Prosentase Kesalahan Siswa dalam Menyelesaikan Soal Fisika Bahasan Termodinamika

\begin{tabular}{ll}
\hline No. & Jenis Kesalahan \\
\hline 1. & Kesalahan Terjemahan \\
\hline 2. & Kesalahan Konsep \\
\hline 3. & Kesalahan Strategi \\
\hline 4. & Kesalahan Hitung \\
\hline
\end{tabular}

1. didapatkan informasi mengenai kesalahankesalahan apa saja yang dilakukan oleh siswa dalam menyelesaikan soal Fisika bahasan Termodinamika melalui tes tertulis berbentuk uraian. Dari analisis data hasil tes, diketahui bahwa siswa melakukan kesalahan terjemahan, konsep, strategi, dan hitung. Jenis kesalahan yang dominan yang paling banyak dilakukan oleh siswa adalah kesalahan strategi dengan prosentase sebesar 60,44

Tabel 2. Prosentase Kesalahan Siswa Tiap Kelas dalam Menyelesaikan Soal Fisika Bahasan Termodinamika

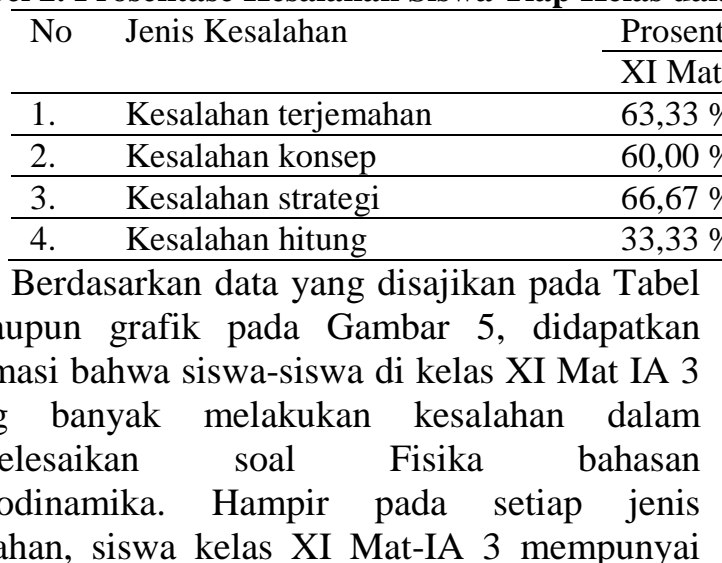


JEMS (Jurnal Edukasi Matematika dan Sains)

Tersedia online di: http://e-journal.ikippgrimadiun.ac.id/index.php/JEMS

Volume 4, Nomor 1, Maret 2016, hal 8 - 17

lebih banyak. Siswa kelas XI Mat-IA 6 mempunyai prosentase kesalahan yang paling sedikit pada kesalahan konsep dibandingkan siswa kelas yang lain. Sedangkan siswa kelas XI Mat-IA 8 mempunyai prosentase kesalahan yang paling sedikit pada kesalahan terjemahan dan strategi dibandingkan siswa kelas yang lain.

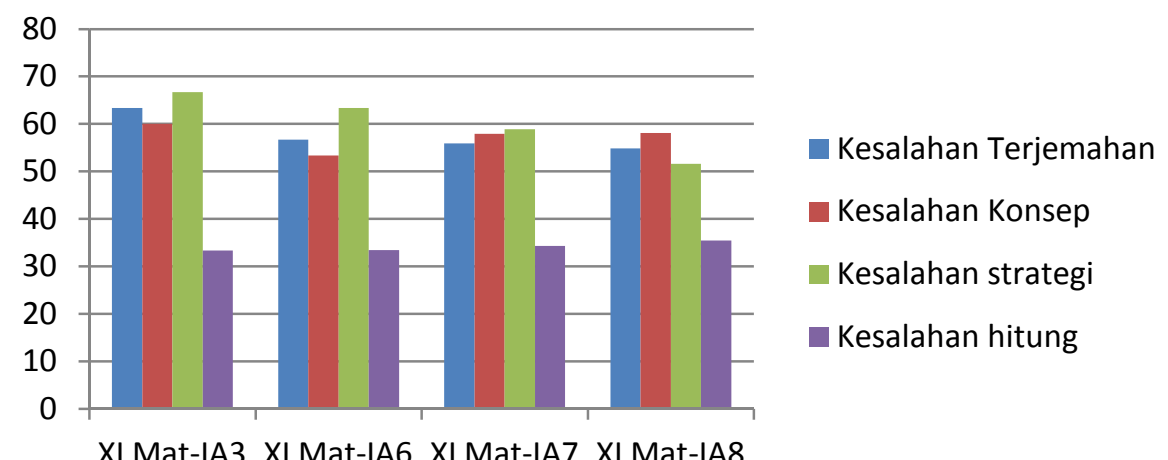

Gambar 5. Prosentase Kesalahan Siswa Tiap Kelas dalam Menyelesaikan Soal Fisika Bahasan Termodinamika

Setelah kesalahan-kesalahan yang terjadi tersebut diketahui, langkah selanjutnya faktor penyebab kesalahan-kesalahan tersebut dapat digali lebih dalam lagi. Jenis kesalahan siswa dalam menyelesaikan soal fisika bahasan Termodinamika yang disajikan pada tabel 1 dapat dirinci lagi untuk prosentase kesalahan pada tiap item soal. Proses kesalahan siswa dalam menyelesaikan soal fisika bahasan Termodinamika pada tiap item soal ditunjukkan pada tabel 3 .

Tabel 3. Prosentase Kesalahan Siswa dalam Menyelesaikan Soal Fisika Bahasan Termodinamika pada tiap item soal

\begin{tabular}{|c|c|c|c|c|c|}
\hline \multirow{2}{*}{ No } & \multirow{2}{*}{ Indikator } & \multicolumn{4}{|c|}{ Prosentase Kesalahan yang Dominan (\%) } \\
\hline & & 1 & 2 & 3 & 4 \\
\hline 1. & $\begin{array}{l}\text { Menerapkan konsep usaha yang dilakukan sistem } \\
\text { pada lingkungannya dalam proses termodinamika. }\end{array}$ & 0,00 & 49,45 & 20,88 & 12,09 \\
\hline 2. & $\begin{array}{l}\text { Menggambarkan diagram gejala Fisika yang } \\
\text { berkaitan dengan proses termodinamika. }\end{array}$ & 7,69 & 20,88 & 16,48 & 0,00 \\
\hline 3. & $\begin{array}{l}\text { Menganalisis permasalahan Fisika yang berkaitan } \\
\text { dengan usaha pada proses termodinamika. }\end{array}$ & 2,20 & 3,30 & 13,19 & 1,10 \\
\hline 4. & $\begin{array}{l}\text { Menganalisis permasalahan Fisika yang berkaitan } \\
\text { dengan kapasitas kalor pada proses } \\
\text { termodinamika }\end{array}$ & 3,30 & 8,79 & 23,08 & 6,59 \\
\hline 5. & $\begin{array}{l}\text { Menganalisis permasalahan Fisika yang berkaitan } \\
\text { dengan Hukum I Termodinamika }\end{array}$ & 1,10 & 27,47 & 14,29 & 3,30 \\
\hline 6. & $\begin{array}{l}\text { Menggunakan } \\
\begin{array}{l}\text { konsep } \\
\text { diagram PV Fisika dalam menganalisis } \\
\text { termodinamika. }\end{array}\end{array}$ & 32,97 & 34,07 & 51,65 & 8,79 \\
\hline 7. & $\begin{array}{l}\text { Menganalisis permasalahan Fisika tentang siklus } \\
\text { Carnot dalam mesin Carnot dengan efisiensi mesin } \\
\text { Carnot. }\end{array}$ & 49,45 & 13,19 & 20,88 & 2,20 \\
\hline 8. & $\begin{array}{l}\text { Menggunakan efisiensi mesin } \text { Carnot } \\
\text { menganalisis permasalahan } \\
\text { Carnot. }\end{array}$ & 30,77 & 10,99 & 10,99 & 1,10 \\
\hline 9. & $\begin{array}{l}\text { Menganalisis gejala Fisika yang berkaitan dengan } \\
\text { Hukum II Termodinamika dalam kehidupan sehari- } \\
\text { hari. }\end{array}$ & 16,48 & 13,19 & 16,48 & 4,40 \\
\hline 10. & $\begin{array}{l}\text { Menggunakan koefisien performansi / koefisien daya } \\
\text { guna dalam menganalisis permasalahan Fisika } \\
\text { tentang mesin pendingin. }\end{array}$ & 37,36 & 20,88 & 24,18 & 2,20 \\
\hline
\end{tabular}

Berdasarkan data yang disajikan pada Tabel 3, didapatkan informasi mengenai jenis kesalahan yang dominan yang dilakukan oleh siswa dalam menyelesaikan soal Fisika bahasan
Termodinamika. Dalam penyelesaian soal tersebut, dapat dilihat bahwa jenis kesalahan yang dilakukan oleh siswa 
adalah kesalahan terjemahan, strategi, konsep, dan hitung.

Soal nomor 1 tentang penggunaan konsep usaha yang dilakukan sistem pada lingkungan. Pada soal nomor 1 tidak ditemukan kesalahan terjemahan $(0,00 \%)$. Jenis kesalahan terbanyak yang dilakukan siswa adalah kesalahan konsep $(49,45 \%)$, kemudian diikuti kesalahan strategi $(20,88 \%)$, dan kesalahan hitung (12,09 \%). Berdasarkan hasil observasi ketika pembelajaran dan dari hasil catatan dan pekerjaan siswa, kesalahan siswa pada soal nomor 1 disebabkan adanya kesalahan konsep karena siswa tidak memperhatikan ketika pembelajaran. Kemudian siswa juga salah strategi dengan salah mensubstitusikan besaran yang diketahui pada soal. Selain itu, siswa juga melakukan kesalahan dalam melakukan operasi hitung. Berdasarkan hasil wawancara, kesalahan siswa pada soal nomor 1 disebabkan adanya kesalahan konsep karena siswa tidak memperhatikan ketika pembelajaran. Kemudian siswa juga salah strategi dengan salah mensubstitusikan besaran yang diketahui pada soal karena kurang teliti membaca soal. Selain itu, siswa juga melakukan kesalahan hitung karena kurang teliti dalam melakukan operasi hitung.

Soal nomor 2 tentang menggambar proses Termodinamika pada diagram P-V. Pada soal nomor 2 tidak ditemukan kesalahan hitung $(0,00$ $\%)$. Jenis kesalahan terbanyak yang dilakukan siswa adalah kesalahan konsep (20,88 \%), kemudian diikuti kesalahan strategi $(16,48 \%)$, dan kesalahan terjemahan $(7,69 \%)$. Berdasarkan hasil observasi ketika pembelajaran dan dari hasil catatan dan pekerjaan siswa, kesalahan siswa pada soal nomor 2 disebabkan adanya salah konsep karena siswa tidak memperhatikan ketika pembelajaran. Kemudian siswa juga salah strategi dengan salah mensubstitusikan besaran yang diketahui pada soal. Selain itu, siswa juga melakukan kesalahan terjemahan dalam memahami soal. Berdasarkan hasil wawancara, kesalahan siswa pada soal nomor 2 disebabkan adanya salah konsep karena siswa kurang memperhatikan ketika pembelajaran. Kemudian siswa juga salah strategi dalam menggunakan besar volume yang diketahui pada soal karena kurang teliti dalam membaca soal. Selain itu, siswa juga melakukan kesalahan terjemahan karena kurang memahami maksud soal.
Soal nomor 3 tentang penggunaan konsep proses Termodinamika untuk mencari besar usaha yang dilakukan. Jenis kesalahan terbanyak yang dilakukan siswa adalah kesalahan strategi $(13,19$ $\%)$, kemudian diikuti kesalahan konsep $(3,30 \%)$, kesalahan terjemahan $(2,20 \%)$, dan kesalahan hitung $(1,10 \%)$. Berdasarkan hasil observasi ketika pembelajaran dan dari hasil catatan dan pekerjaan siswa, kesalahan siswa pada soal nomor 3 disebabkan adanya salah terjemahan dalam menuliskan simbol Fisika. Siswa juga salah konsep karena tidak memperhatikan ketika pembelajaran. Kemudian siswa juga salah strategi dengan salah mensubstitusikan besaran yang diketahui pada soal. Selain itu, siswa juga melakukan kesalahan dalam melakukan operasi hitung. Berdasarkan hasil wawancara, kesalahan siswa pada soal nomor 3 disebabkan adanya salah terjemahan karena siswa lupa dan kurang teliti dalam menuliskan data yang diketahui ke dalam simbol Fisika. Siswa juga salah konsep karena kurang memperhatikan ketika pembelajaran dan tidak berani mengajukan pertanyaan ketika ada materi yang belum paham. Kemudian siswa juga salah strategi dengan salah mensubstitusikan besaran yang diketahui pada soal karena terburu-buru dan kurang teliti membaca data yang diketahui pada soal. Selain itu, siswa juga melakukan kesalahan hitung karena kurang teliti dalam menghitung.

Soal nomor 4 tentang penggunaan kapasitas kalor. Jenis kesalahan terbanyak yang dilakukan siswa adalah kesalahan strategi $(23,08 \%)$, kemudian diikuti kesalahan konsep (8,79 \%), kesalahan hitung $(6,59 \%)$, dan kesalahan terjemahan $(3,30 \%)$. Berdasarkan hasil observasi ketika pembelajaran dan dari hasil catatan dan pekerjaan siswa, kesalahan siswa pada soal nomor 4 disebabkan adanya salah terjemahan dalam memahami maksud soal. Siswa juga salah konsep karena tidak memperhatikan ketika pembelajaran. Kemudian siswa juga salah strategi karena langkah penyelesaian soal yang digunakan kurang tepat. Selain itu, siswa juga melakukan kesalahan dalam melakukan operasi hitung. Berdasarkan hasil wawancara, kesalahan siswa pada soal nomor 4 disebabkan adanya salah terjemahan karena siswa terburu-buru sehingga kurang teliti dalam memahami maksud soal. Siswa juga salah konsep karena kurang memperhatikan ketika pembelajaran dan tidak berani mengajukan pertanyaan ketika ada materi yang belum paham. Kemudian siswa juga 
salah strategi dengan mengerjakan menggunakan langkah penyelesaian soal yang digunakan kurang tepat karena kurang latihan soal dan kurang variasi dalam latihan penyelesaian soal. Selain itu, siswa juga melakukan kesalahan hitung karena terburuburu dalam mengerjakan.

Soal nomor 5 tentang penggunaan Hukum I Termodinamika. Jenis kesalahan terbanyak yang dilakukan siswa adalah kesalahan konsep $(27,47 \%)$, kemudian diikuti kesalahan strategi $(14,29 \%)$, kesalahan hitung $(3,30 \%)$, dan kesalahan terjemahan $(1,10 \%)$.

Berdasarkan hasil observasi ketika pembelajaran dan dari hasil catatan dan pekerjaan siswa, kesalahan siswa pada soal nomor 5 disebabkan adanya salah terjemahan dalam menuliskan data yang diketahui pada soal. Siswa juga salah konsep karena tidak memperhatikan ketika pembelajaran.

Kemudian siswa juga salah strategi dengan langkah penyelesaian soal yang digunakan kurang tepat. Selain itu, siswa juga melakukan kesalahan dalam melakukan operasi hitung. Berdasarkan hasil wawancara, kesalahan siswa pada soal nomor 5 disebabkan adanya salah konsep karena siswa kurang memperhatikan ketika pembelajaran. Kemudian siswa juga salah strategi dalam pemilihan langkah penyelesaian karena kurang variasi dalam latihan penyelesaian soal. Siswa juga melakukan kesalahan terjemahan karena kurang teliti dalam menuliskan data yang diketahui pada soal. Selain itu, siswa juga melakukan kesalahan hitung karena kurang teliti dalam menghitung. Soal nomor 6 tentang siklus Termodinamika. Jenis kesalahan terbanyak yang dilakukan siswa adalah kesalahan strategi $(51,65 \%)$, kemudian diikuti kesalahan konsep $(34,07 \%)$, kesalahan terjemahan $(32,97 \%)$, dan kesalahan hitung $(8,79 \%)$.

Berdasarkan hasil observasi ketika pembelajaran dan dari hasil catatan dan pekerjaan siswa, kesalahan siswa pada soal nomor 6 disebabkan adanya kesalahan strategi dalam pemilihan langkah penyelesaian soal yang kurang tepat. Siswa juga salah konsep karena tidak memperhatikan ketika pembelajaran. Kemudian siswa juga melakukan kesalahan terjemahan dalam mengartikan maksud soal. Selain itu, siswa juga melakukan kesalahan dalam melakukan operasi hitung. Berdasarkan hasil wawancara, kesalahan siswa pada soal nomor 6 disebabkan adanya salah strategi dalam pemilihan langkah penyelesaian karena kurang latihan soal, kurang variasi dalam latihan penyelesaian soal, terburu-buru, dan kekurangan waktu. Kemudian siswa juga salah konsep karena siswa kurang memperhatikan ketika pembelajaran. Siswa juga melakukan kesalahan terjemahan karena siswa salah mengartikan maksud soal, dan kurang teliti dalam membaca serta memahami maksud soal. Selain itu, siswa juga melakukan kesalahan hitung karena kurang teliti dalam menghitung dan terburu-buru dalam mengerjakan.

Soal nomor 7 tentang penggunaan efisiensi mesin Carnot. Jenis kesalahan terbanyak yang dilakukan siswa adalah kesalahan terjemahan $(49,45 \%)$, kemudian diikuti kesalahan strategi $(20,88 \%)$, kesalahan konsep $(13,19 \%)$, dan kesalahan hitung $(2,20 \%)$. Berdasarkan hasil observasi ketika pembelajaran dan dari hasil catatan dan pekerjaan siswa, kesalahan siswa pada soal nomor 7 disebabkan adanya kesalahan terjemahan dalam mengartikan maksud soal. Kemudian siswa juga melakukan kesalahan strategi dalam penentuan langkah penyelesaian soal. Kemudian siswa juga melakukan kesalahan konsep karena tidak memperhatikan ketika pembelajaran. Selain itu, siswa juga melakukan kesalahan dalam melakukan operasi hitung. Berdasarkan hasil wawancara, kesalahan siswa pada soal nomor 7 disebabkan adanya kesalahan terjemahan karena siswa salah mengartikan maksud soal, dan kurang teliti dalam membaca serta memahami maksud soal. Siswa juga melakukan kesalahan strategi dalam penentuan langkah penyelesaian soal karena kurang teliti, kurang latihan dalam penyelesaian soal, dan kurang variasi dalam latihan penyelesaian soal. Kemudian siswa juga salah konsep karena siswa kurang belajar, kurang memperhatikan penjelasan guru, dan tidak berani mengajukan pertanyaan ketika ada materi yang belum dipahami. Selain itu, siswa juga melakukan kesalahan hitung karena kurang teliti dalam menghitung dan terburu-buru dalam mengerjakan.

Soal nomor 8 tentang perubahan suhu yang berkaitan dengan efisiensi mesin Carnot. Jenis kesalahan terbanyak yang dilakukan siswa adalah kesalahan terjemahan $(30,77 \%)$, kemudian diikuti kesalahan konsep $(10,99 \%)$ dan kesalahan strategi $(10,99 \%)$, serta kesalahan hitung $(1,10 \%)$.

Berdasarkan hasil observasi ketika pembelajaran dan dari hasil catatan dan pekerjaan 
siswa, kesalahan siswa pada soal nomor 8 disebabkan adanya kesalahan terjemahan karena salah menuliskan simbol Fisika dari data-data yang disebutkan pada soal dan kurang teliti dalam memahami maksud soal. Kemudian siswa juga melakukan kesalahan strategi dalam penentuan langkah penyelesaian soal dan kurang teliti. Kemudian siswa juga melakukan kesalahan konsep karena tidak memperhatikan ketika pembelajaran. Selain itu, siswa juga melakukan kesalahan dalam melakukan operasi hitung. Berdasarkan hasil wawancara, kesalahan siswa pada soal nomor 8 disebabkan adanya kesalahan terjemahan karena siswa lupa, tidak memahami simbol Fisika dari data-data yang disebutkan pada soal dan kurang teliti dalam memahami maksud soal. Siswa juga melakukan kesalahan strategi dalam penentuan langkah penyelesaian soal karena kurang teliti, kurang latihan soal, kurang variasi dalam latihan penyelesaian soal, terburu-buru, dan kekurangan waktu. Kemudian siswa juga melakukan kesalahan konsep karena siswa kurang belajar, kurang memperhatikan penjelasan guru, dan tidak berani mengajukan pertanyaan ketika ada materi yang belum dipahami. Selain itu, siswa juga melakukan kesalahan hitung karena kurang teliti dalam menghitung dan terburu-buru dalam mengerjakan.

Soal nomor 9 tentang perubahan entropi pada proses pengembunan. Jenis kesalahan terbanyak yang dilakukan siswa adalah kesalahan terjemahan $(16,48 \%)$ dan kesalahan strategi $(16,48$ $\%)$, kemudian diikuti kesalahan konsep $(13,19 \%)$, dan kesalahan hitung $(4,40 \%)$. Berdasarkan hasil observasi ketika pembelajaran dan dari hasil catatan dan pekerjaan siswa, kesalahan siswa pada soal nomor 9 disebabkan adanya kesalahan terjemahan karena salah menuliskan simbol Fisika dari data-data yang disebutkan pada soal dan salah mengartikan maksud soal. Kemudian siswa juga melakukan kesalahan strategi dalam penentuan langkah penyelesaian soal dan kurang teliti. Kemudian siswa juga melakukan kesalahan konsep karena tidak memperhatikan ketika pembelajaran. Selain itu, siswa juga melakukan kesalahan dalam melakukan operasi hitung. Berdasarkan hasil wawancara, kesalahan siswa pada soal nomor 9 disebabkan adanya kesalahan terjemahan karena iswa lupa dan tidak memahami simbol Fisika dari data-data yang disebutkan pada soal. Siswa juga melakukan kesalahan strategi dalam penentuan langkah penyelesaian soal karena lupa, kurang teliti, kurang latihan soal, kurang variasi dalam latihan penyelesaian soal, terburu-buru, dan kekurangan waktu. Kemudian siswa juga melakukan kesalahan konsep karena kurang belajar, kurang memperhatikan penjelasan guru, dan tidak berani mengajukan pertanyaan ketika ada materi yang belum dipahami. Selain itu, siswa juga melakukan kesalahan hitung karena kurang teliti dalam menghitung.

Soal nomor 10 tentang mesin pendingin. Jenis kesalahan terbanyak yang dilakukan siswa adalah kesalahan terjemahan $(37,36 \%)$, kemudian diikuti kesalahan strategi $(24,18 \%)$, kesalahan konsep $(20,88 \%)$, dan kesalahan hitung $(2,20 \%)$. Berdasarkan hasil observasi ketika pembelajaran dan dari hasil catatan dan pekerjaan siswa, kesalahan siswa pada soal nomor 10 disebabkan adanya kesalahan terjemahan karena salah menuliskan simbol Fisika dari data-data yang disebutkan pada soal dan salah mengartikan maksud soal. Kemudian siswa juga melakukan kesalahan strategi dalam penentuan langkah penyelesaian soal dan kurang teliti. Kemudian siswa juga melakukan kesalahan konsep karena tidak memperhatikan ketika pembelajaran. Selain itu, siswa juga melakukan kesalahan dalam melakukan operasi hitung. Berdasarkan hasil wawancara, kesalahan siswa pada soal nomor 10 disebabkan adanya kesalahan terjemahan karena siswa lupa, tidak memahami simbol Fisika dari data-data yang disebutkan pada soal, dan kurang teliti dalam membaca serta memahami maksud soal. Siswa juga melakukan kesalahan strategi dalam penentuan langkah penyelesaian soal karena kurang teliti, kurang latihan soal, kurang variasi dalam latihan penyelesaian soal, terburu-buru, dan kekurangan waktu. Kemudian siswa juga melakukan kesalahan konsep karena siswa kurang belajar, kurang memperhatikan penjelasan guru, dan tidak berani mengajukan pertanyaan ketika ada materi yang belum dipahami. Selain itu, siswa juga melakukan kesalahan hitung karena kurang teliti dalam menghitung dan terburu-buru dalam mengerjakan.

Berdasarkan jenis kesalahan dan penyebab kesalahan yang dilakukan siswa dalam menyelesaikan soal Fisika bahasan Termodinamika, maka dapat dikemukakan beberapa cara untuk mengatasi terjadinya kesalahan tersebut, yaitu: 
(1). Guru diharapkan memberikan motivasi kepada siswa dalam kegiatan pembelajaran sehingga siswa menyukai pembelajaran Fisika. Guru diharapkan lebih sering memberikan latihan dan tugas untuk menyelesaikan soal-soal Fisika yang bervariasi disertai pembahasannya. (3) Guru diharapkan memperjelas konsep yang diberikan kepada siswa pada bahasan Termodinamika, yaitu konsep usaha yang dilakukan lingkungan pada sistem, proses Termodinamika, usaha pada proses Termodinamika, kapasitas kalor, Hukum I Termodinamika, perubahan energi dalam, siklus Termodinamika, mesin Carnot, perubahan entropi, dan mesin pendingin, serta mengkonversikan ke satuan Internasional (SI). (4) Guru diharapkan lebih sering mengingatkan siswa untuk lebih teliti dalam membaca soal dan menghitung, serta meneliti kembali pekerjaannya jika telah selesai mengerjakan.(5) Siswa diharapkan lebih berkonsentrasi dalam belajar dan aktif dalam kegiatan pembelajaran. (6) Siswa diharapkan lebih rajin dalam belajar, mengerjakan soal-soal, dan bertanya kepada guru apabila ada materi yang belum dipahami.

\section{KESIMPULAN}

Jenis kesalahan yang dilakukan oleh siswa dalam menyelesaikan soal Fisika pada bahasan Termodinamika adalah: (a) Kesalahan terjemahan berupa kesalahan dalam menuliskan apa yang diketahui dan ditanyakan pada soal ke dalam simbol Fisika, memahami maksud soal, serta menuliskan data yang diketahui pada soal secara tepat; (b) Kesalahan konsep berupa kesalahan dalam memahami konsep usaha yang dilakukan lingkungan pada sistem, proses Termodinamika, usaha pada proses Termodinamika, kapasitas kalor, Hukum I Termodinamika, perubahan energi dalam, siklus termodinamika, mesin Carnot, perubahan entropi, dan mesin pendingin, serta mengkonversikan ke Satuan Internasional (SI); (c) Kesalahan strategi berupa kesalahan dalam menggunakan data dan dalam penentuan langkah penyelesaian soal; (d) Kesalahan hitung berupa kesalahan dalam melakukan operasi hitung.

Penyebab kesalahan siswa dalam menyelesaikan soal Fisika pada materi Termodinamika adalah: (a) Penyebab kesalahan terjemahan adalah siswa lupa, tidak memahami simbol Fisika dari data-data yang disebutkan pada soal, salah mengartikan maksud soal, dan kurang teliti dalam membaca serta memahami maksud soal; (b.) Penyebab kesalahan konsep adalah siswa kurang belajar, kurang memperhatikan penjelasan guru, dan tidak berani mengajukan pertanyaan ketika ada materi yang belum dipahami.

\section{DAFTAR PUSTAKA}

Ornek et all. (2008). "What makes physic difficult?". International Journal of Enviromental \& Science Education. 3(1). 30-34

Suparno, P. (2009). Kajian Kurikulum Fisika SMA/MA Berdasakan KTSP. Yogyakarta: Universitas Sanata Dharma.

Sutopo, H.B. (2006). Metodologi Penelitian Kualitatif Dasar Teori dan Terapannya dalam Penelitian. Surakarta: UNS Press.

Yusro, A. C. (2015). PENGEMBANGAN MODUL PEMBELAJARAN FISIKA BERBASIS KONTEKSTUAL YANG TERINTEGRASI DENGAN WEBSITE PADA SISWA KELAS XI IA SMA NEGERI 5 MADIUN TAHUN AJARAN 2012/2013 (Doctoral dissertation, Universitas Sebelas Maret). 